\title{
De relatie tussen medische consumptie en verzuim bij personeel van een groot ziekenhuis
}

\author{
Romy Steenbeek, ${ }^{1}$ Jan Fekke Ybema ${ }^{1}$
}

\begin{abstract}
Een hogere medische consumptie gaat samen met een hoger verzuim, maar het is niet bekend hoe deze factoren elkaar beïnvloeden over de tijd. In dit onderzoek kijken we daarom specifiek naar de longitudinale relatie tussen medische consumptie en verzuim. Het onderzoek is uitgevoerd onder 2317 werknemers in loondienst bij een groot ziekenhuis (respons 44\%). De onderzoeksgegevens bestaan uit geregistreerde verzuimgegevens en geregistreerde medische consumptie (kosten voor huisartsbezoek en overige medische kosten) over vier opeenvolgende kwartalen. Bij de analyse van de gegevens over de tijd maken we gebruik van covariantiestructuuranalyse met LISREL. Uit dit onderzoek blijkt dat medische consumptie in het ene kwartaal een deel van het verzuim in het volgende kwartaal voorspelt. De resultaten verschillen bij werknemers met en zonder chronische aandoening. Alleen bij werknemers met een chronische aandoening voorspellen huisartskosten het verzuim. Overige medische kosten zijn niet voorspellend voor verzuim bij werknemers met of zonder chronische aandoening. Deze resultaten leiden tot de aanbeveling dat huisartsen extra alert zouden moeten zijn bij werknemers met een chronische aandoening die op het spreekuur komen omdat zij mogelijk (meer) gaan verzuimen. De huisarts kan dan samen met de werknemer kijken of verzuim tot een minimum beperkt of voorkomen kan worden.
\end{abstract}

Trefwoorden: medische consumptie, verzuim, huisartsbezoek, werknemers, chronische aandoening

\section{INLEIDING}

Zowel medische consumptie als verzuim vormen hoge kostenposten. Daarom hebben ziektekostenverzekeraars baat bij lage ziektekosten en werkgevers en werknemers bij een laag verzuim en goede zorgverlening bij gezondheidsproblemen. Het is echter nog onduidelijk hoe medische consumptie en verzuim elkaar beïnvloeden. Een beter begrip van deze relatie kan helpen om de zorgverlening effectiever te laten verlopen en daardoor het verzuim mogelijk te verlagen. Daarom concentreren we ons in dit onderzoek specifiek op de relatie tussen medische consumptie (ziektekosten) en verzuim.

Andere onderzoeken laten zien dat er een positief verband bestaat tussen medische consumptie en verzuim. Werknemers zoeken vaker hulp bij zorgverleners wanneer zij gezondheidsklachten ontwikkelen ${ }^{1-4}$ of een chronische aandoening hebben. ${ }^{2,5-9}$ Ook is bekend dat een hogere medische consumptie samenhangt met een hoger verzuim. De huisarts wordt bijvoorbeeld vaker bezocht wanneer mensen langdurig verzuimen. ${ }^{10}$ Hogere medische kosten vanwege lage rugpijn blijken bij verplegend personeel onder meer samen te hangen met een hoger verzuim. ${ }^{11}$ Verder vonden Latinen-Krispijn en Bijl ${ }^{6}$ een sterk verband tussen zorggebruik in verband met

${ }^{1}$ TNO Kwaliteit van Leven / Arbeid, Hoofddorp psychische problemen en ziekteverzuim in de voorafgaande twaalf maanden bij werknemers. Joish et al. ${ }^{12}$ laten zien dat werknemers met klachten in verband met maagzuur of een maagzweer hogere medische kosten hebben wat betreft farmacie en niet-klinische zorg en ook een hoger verzuim. White et al., ${ }^{13}$ ten slotte, vonden dat werknemers met pijnklachten (in relatie tot kanker, artritis, rug/nek aandoeningen, neuropathische pijn) 1,5 tot 3,5 keer zoveel kosten als de gemiddelde werknemer aan directe kosten (medische consumptie) en indirecte kosten (bijvoorbeeld verzuimkosten).

$\mathrm{Er}$ is nog vrijwel geen onderzoek gedaan naar longitudinale verbanden tussen medische consumptie en verzuim. Molano et al. ${ }^{14}$ concluderen in een studie bij steigerbouwers naar hulpzoekgedrag bij lage rugklachten dat het hebben van uitstralende pijn en verzuim de beste voorspellers waren voor het zoeken van medische hulp en het verwezen worden naar een specialist of fysiotherapeut. Dit betrof echter cross-sectionele data. Houtman et al. ${ }^{15}$ vonden dat onder meer huisartsbezoek of een bezoek aan een psycholoog in de voorafgaande twee maanden de kans op terugkeer naar werk verkleint bij werknemers die langdurig verzuimden vanwege psychische klachten. Nieuwenhuijsen et al., ${ }^{16}$ ten slotte, rapporteren vergelijkbare resultaten: een hogere frequentie van bezoeken aan zorgverleners hing samen met een latere (gedeelte- 
lijke) terugkeer naar werk bij werknemers die verzuimden vanwege psychische problemen. De twee longitudinale studies bevatten aanwijzingen dat een toename in medische consumptie voorafgaat aan een toename in verzuim, maar deze studies zijn beperkt tot werknemers die verzuimen vanwege psychische klachten.

Wanneer medische consumptie vooraf gaat aan verzuim kan sprake zijn van ernstige gezondheidsklachten die niet direct met een bezoek aan een zorgverlener zijn te verhelpen. In dit geval is de medische consumptie een signaal van de ernst van de klachten en een indicator dat verzuim kan volgen. Het kan ook zijn dat verzuim vooraf gaat aan medische consumptie. In dit geval vormen gezondheidsproblemen waardoor men verzuimt de reden om hulp te zoeken bij een zorgverlener.

\section{METHODE}

\section{Onderzoekspopulatie en dataverzameling}

De onderzoekspopulatie bestaat uit werknemers in loondienst bij een groot ziekenhuis die allen zijn verzekerd bij één ziektekostenverzekeraar. De gegevens die gebruikt zijn voor dit onderzoek zijn afkomstig uit drie bronnen:

1 Een vragenlijstonderzoek onder werknemers, waar we onder meer vroegen naar de hoogst voltooide opleiding en het hebben van een chronische aandoening ('heeft u last van een langdurige ziekte en/of aandoening?');

2 Persoons- en verzuimgegevens afkomstig van de afdeling $\mathrm{P} \& \mathrm{O}$ van het ziekenhuis (waaronder geslacht en leeftijd);

3 Gegevens over de medische consumptie van de ziektekostenverzekeraar.

We hebben gekozen om de gegevens te analyseren van het eerste jaar dat deze zorgverzekeraar de werknemers van dit ziekenhuis verzekerde (01-10-2002 t/m 30-09-2003). We noemen dit het onderzoeksjaar.

De vragenlijstgegevens zijn gekoppeld aan de andere datasets met behulp van een anoniem onderzoeksnummer. Gegevens waren dus niet herleidbaar tot personen. Werknemers gaven op de teruggestuurde vragenlijst wel of geen schriftelijke toestemming om de gegevens te koppelen met de andere gegevens.

In totaal zijn 6290 vragenlijsten verstuurd waarvan er 2768 zijn geretourneerd met toestemming van de werknemer om de data te koppelen (respons 44\%, 97 werknemers gaven geen toestemming - deze vragenlijsten zijn niet gebruikt). Een gedeelte van de werknemers is uitgesloten van de analyses. Ten eerste werknemers die korter dan drie maanden in dienst waren toen zij de vragenlijst invulden $(n=28)$. Ten tweede werknemers die in het on- derzoeksjaar zwanger waren $(n=198)$. Dit omdat we de analyses willen uitvoeren op verzuimgegevens exclusief zwangerschap. Ten derde werknemers die niet het gehele onderzoeksjaar in dienst waren $(n=225)$. Uiteindelijk konden de analyses worden uitgevoerd op de gegevens van 2317 respondenten.

\section{Operationalisatie verzuim en medische consumptie}

Voor dit onderzoek hebben we voor iedere deelnemer aan het onderzoek de ruwe gegevens over het ziekteverzuim (datum van ziekmelding en herstelmelding) gekregen uit de personeelsregistratie van het bedrijf. Deze gegevens hebben we zodanig bewerkt dat we per persoon per kwartaal een verzuimpercentage kregen. Dit verzuimpercentage ligt tussen 0 en $100 \%$. Van de ziektekostenverzekeraar kregen we voor diezelfde kwartalen de kosten die in dat kwartaal gedeclareerd waren. Omdat niet iedereen een aanvullende verzekering heeft afgesloten hebben wij alleen vergoedingen die onder het standaardpakket vallen en in het onderzoeksjaar zijn uitgekeerd in dit onderzoek meegenomen (dit betreft nog het oude verzekeringsstelsel). Deze kosten zijn uitgesplitst naar kosten voor (a) huisartsbezoek en (b) overige medische kosten (ziekenhuisen specialistbezoek, paramedische zorg, farmaceutische producten, revalidatie en hulpmiddelen). Deze overige kosten hebben we bij elkaar opgeteld omdat elk van deze kosten (behalve farmaceutische kosten) relatief weinig voorkwam. Vooral bij ziekenhuiskosten en kosten voor revalidatie betrof het echter wel relatief hoge bedragen.

De oorspronkelijke variabelen zijn sterk scheef verdeeld. Een aanzienlijk aantal personen verzuimt niet en heeft geen medische consumptie. Sommigen hebben echter een heel hoog verzuim of een heel hoge medische consumptie. Daarom zijn logaritmische transformaties toegepast voor zowel de verzuimmaten als voor de medische consumptiematen. Hierdoor worden de variabelen meer normaal verdeeld en wordt de invloed van extreme waarden op de resultaten beperkt.

\section{Het onderzoeksmodel}

In dit onderzoek kijken we specifiek naar longitudinale verbanden tussen medische consumptie en verzuim. Als indicator voor medische consumptie gebruiken we de medische kosten die een persoon per kwartaal maakt. Hierbij onderscheiden we kosten voor huisartsbezoek van overige medische kosten. In dit onderzoek controleren we deels voor de invloed van gezondheidsproblemen. We nemen als uitgangspunt dat gezondheidsproblemen zowel kunnen leiden tot een hogere medische consumptie als tot verzuim en ook de relatie tussen die twee kunnen beïnvloeden. Aangezien werknemers met een chronische aandoening én een hogere medische consumptie én een 
hoger verzuim hebben zullen de onderlinge relaties tussen medische consumptie en verzuim voor een belangrijk deel gestuurd worden door het wel of niet hebben van een chronische aandoening. Daarom zijn beide groepen (werknemers met en zonder een chronische aandoening) gelijktijdig in één model opgenomen waarna getoetst is of hun coëfficiënten al dan niet gelijk waren (meergroepenmethode). De aard en ernst van chronische aandoeningen zullen ook een rol spelen, maar blijven noodgedwongen buiten beschouwing in dit onderzoek.

\section{Analyse}

Bij de vergelijking tussen groepen betreffende de gegevens over het hele jaar maken we gebruik van een Chikwadraat toets (aantal werknemers) of een t-toets (verzuimpercentage en kosten).

Bij de analyse van de gegevens over de tijd maken we gebruik van covariantiestructuuranalyse met LISREL (versie 8.51). We analyseren daarbij hoe huisartskosten, overige medische kosten en ziekteverzuim binnen één kwartaal onderling samenhangen. Daarnaast gaan we na hoe stabiel medische consumptie en ziekteverzuim in de tijd zijn. De stabiliteit wordt aangeduid in de tabellen als gestandaardiseerde en ongestandaardiseerde regressiegewichten. Vervolgens gaan we na welke longitudinale relaties er bestaan tussen huisartskosten, overige medische kosten en ziekteverzuim. Dit laatste is het meest interessante aspect van het onderzoek. We kijken of medische consumptie voorspellend is voor ziekteverzuim in het volgende kwartaal, rekening houdend met het huidige ziekteverzuim. Ook gaan we na of ziekteverzuim voorspellend is voor medische consumptie in het volgende kwartaal, rekening houdend met de medische consumptie in het huidige kwartaal. Ten slotte gaan we na hoe huisartskosten voorspellend zijn voor overige medische kosten en omgekeerd hoe overige medische kosten huisartskosten voorspellen. Omdat we over vier kwartalen (K1, K2, K3, K4) gegevens verzameld hebben, komt elk van deze longitudinale relaties drie maal voor. Omdat we vooral geïnteresseerd zijn in de samenhang tussen medische kosten en verzuim, laten we in het model niet toe dat de parameter voor deze samenhang meer dan één waarde heeft, ook al zal die in de werkelijkheid van kwartaal tot kwartaal verschillen. In dit model stellen we daarom steeds de overeenkomstige relaties aan elkaar gelijk. Bijvoorbeeld: het effect van huisartskosten in K1 op ziekteverzuim in $\mathrm{K} 2$ is dus gelijkgesteld aan het effect van huisartskosten in K2 op ziekteverzuim in K3. Vervolgens hebben we de meergroepenmethode gebruikt. Ook hier stellen we de pijlen in eerste instantie aan elkaar gelijk om na te gaan of de modellen in beide groepen (mensen met en mensen zonder chronische aandoening) identiek zijn.

Alle effecten zijn gecorrigeerd voor geslacht, leeftijd en opleiding door deze demografische variabelen als predictoren in het model op te nemen met (voor ieder kwartaal identieke) paden naar huisartskosten, overige medische kosten en ziekteverzuim. Dit is gedaan omdat verzuim samenhangt met deze demografische variabelen. ${ }^{20}$ Ook medische consumptie blijkt met deze persoonsfactoren samen te hangen. Vrouwen consulteren artsen vaker dan mannen. ${ }^{1,2,6,17}$ Ouderen bezoeken artsen vaker dan jongeren. ${ }^{5,6}$ Opleiding heeft soms geen invloed, ${ }^{6,18}$ soms gaat een hogere opleiding samen met een lager ${ }^{5,8}$ en soms met een hoger artsbezoek. ${ }^{2}$

In de LISREL-analyses wordt de covariantiematrix geanalyseerd met behulp van de Maximum Likelihood (ML) methode. De fit van het getoetste model in LISREL wordt geëvalueerd met behulp van de Chi-kwadraattoets, de comparative fit index (CFI), de nonnormed fit index (NNFI) en de standardized root means square residual (SRMR). Waarden van 0,95 of hoger voor de CFI en de NNFI geven een goede fit aan en ditzelfde geldt voor waarden van 0,08 of lager voor de SRMR. ${ }^{2,22}$

\section{RESULTATEN}

\section{Beschrijvende resultaten}

Van de respondenten is $72 \%$ vrouw, heeft $64 \%$ een $\mathrm{HBO}$ of hogere opleiding en is de gemiddelde leeftijd 40,9 jaar (sd 10,1 jaar). Van deze werknemers werkt 44\% 36 uur of langer, 39\% werkt 24-35 uur en 17\% werkt minder dan 24 uur per week. De responsgroep lijkt in de meeste opzichten op de totale groep werknemers. Een verschil is dat de totale groep iets vaker meer dan 36 uur per week werkt (49\% versus 44\%). Gegevens over het opleidingsniveau van de totale groep zijn onbekend.

In tabel 1 staat voor ieder kwartaal en voor het gehele onderzoeksjaar het percentage werknemers dat heeft verzuimd en het percentage werknemers dat medische kosten heeft gemaakt voor de categorieën huisarts en overig. Ook staat in deze tabel per kwartaal en voor het onderzoeksjaar het verzuimpercentage, de gemiddelde kosten voor de categorieën huisarts en overig. Deze getallen zijn weergegeven voor de hele onderzoekspopulatie en gesplitst naar werknemers zonder $(\mathrm{N}=1495)$ en met een chronische aandoening $(\mathrm{N}=822,35 \%)$. Uit een analyse van de gegevens over het hele onderzoeksjaar blijkt uit een vergelijking tussen werknemers met en zonder chronische aandoening dat een significant hoger percentage werknemers met een chronische aandoening minimaal één keer heeft verzuimd, minimaal één keer de huisarts heeft bezocht en minimaal één keer overige medische kosten heeft gemaakt. Tevens blijkt dat werknemers met een chronische aandoening een significant hoger verzuimpercentage hebben, hogere huisartskosten en hogere overige kosten hebben gemaakt dan werknemers zonder chronische aandoening (aangegeven met ${ }^{\star * *}$ in tabel 1).

\section{Relatie tussen huisartskosten en verzuim}

Uit de LISREL-analyses komt naar voren dat het model waarin de kosten van huisartsbezoek en overige medische kosten worden gerelateerd aan ziekteverzuim significant verschilt tussen werknemers met en zonder chronische aandoening (noot onder tabel 2). Het resulterend model is een goede weergave van de gegevens. In tabel 2 is weergegeven welke gewichten deze paden hebben en welke van de paden in het model significant zijn.

Uit tabel 2 blijkt dat huisartskosten, overige medische kosten en verzuim binnen een kwartaal onderling positief 
Tabel 1 Verzuim en medische consumptie per kwartaal voor werknemers met en zonder chronische aandoening

\begin{tabular}{|c|c|c|c|c|c|}
\hline Alle werknemers $(n=2317)$ & K1 & K2 & $K_{3}$ & $K_{4}$ & hele jaar \\
\hline \% werknemers met verzuim & 32,8 & 35,9 & 29,2 & 27,3 & $61,9^{\star \star \star}$ \\
\hline$\%$ werknemers met kosten huisarts & 32,5 & 34,5 & 33,1 & 29,3 & $59,3^{\star \star \star}$ \\
\hline$\%$ werknemers met kosten overig & 40,8 & 45,0 & 50,6 & 50,8 & $74,8^{\star \star \star}$ \\
\hline Gemiddeld verzuim (\%) & 4,6 & 4,9 & 4,7 & 4,7 & $4,8^{\star \star \star}$ \\
\hline Gemiddelde kosten huisarts $(€)$ & 12,00 & 13,97 & 12,57 & 12,84 & $51,39^{\star \star *}$ \\
\hline Gemiddelde kosten overig $(€)$ & 112,70 & 119,40 & 173,99 & 206,73 & $612,87^{\star \star \star}$ \\
\hline $\begin{array}{l}\text { Werknemers zonder chronische aandoening } \\
(n=1495)\end{array}$ & K1 & K2 & K3 & $\mathrm{K}_{4}$ & hele jaar \\
\hline$\%$ werknemers met verzuim & 26,0 & 30,5 & 23,4 & 20,0 & 55,8 \\
\hline$\%$ werknemers met kosten huisarts & 25,2 & 27,1 & 26,8 & 22,5 & 52,0 \\
\hline$\%$ werknemers met kosten overig & 32,9 & 35,1 & 41,4 & 39,9 & 67,4 \\
\hline Gemiddeld verzuim (\%) & 2,0 & 2,3 & 1,7 & 1,6 & 1,9 \\
\hline Gemiddelde kosten huisarts $(€)$ & 8,69 & 9,32 & 8,62 & 8,18 & 34,82 \\
\hline Gemiddelde kosten overig $(€)$ & 53,20 & 51,99 & 94,36 & 67,53 & 267,04 \\
\hline $\begin{array}{l}\text { Werknemers met chronische aandoening } \\
(\mathrm{n}=\mathbf{8 2 2})\end{array}$ & K1 & K2 & $K_{3}$ & $\mathrm{~K}_{4}$ & hele jaar \\
\hline$\%$ werknemers met verzuim & 45,8 & 46,3 & 40,1 & 41,2 & 73,5 \\
\hline$\%$ werknemers met kosten huisarts & 46,6 & 48,7 & 45,1 & 42,4 & 73,3 \\
\hline$\%$ werknemers met kosten overig & 55,7 & 63,8 & 68,3 & 71,7 & 88,9 \\
\hline Gemiddeld verzuim (\%) & 9,6 & 10,0 & 10,3 & 10,5 & 10,3 \\
\hline Gemiddelde kosten huisarts $(€)$ & 18,35 & 22,88 & 20,14 & 21,76 & 83,12 \\
\hline Gemiddelde kosten overig $(€)$ & 226,90 & 248,51 & 326,47 & 473,32 & 1275,16 \\
\hline
\end{tabular}

$\mathrm{K}_{1}=$ vierde kwartaal 2002; K2 = eerste kwartaal 2003; K3 = tweede kwartaal 2003; K4 = derde kwartaal 2003.

${ }^{\star \star \star}=$ werknemers met een chronische aandoening scoren significant $(p<0,001)$ en relevant $(=0,2$ sd) hoger dan werknemers zonder chronische aandoening.

samenhangen: mensen die vaker naar de huisarts gaan, maken ook gemiddeld hogere kosten voor overige medische consumptie en hebben gemiddeld genomen een hoger verzuimpercentage. Dit geldt voor alle werknemers. Verder blijkt dat er voor huisartskosten, voor overige medische kosten en voor verzuim sprake is van een zekere mate van stabiliteit. Dit is vooral het geval voor het verzuim van mensen met een chronische aandoening: mensen die in het ene kwartaal meer verzuimen, verzui- men ook relatief meer in het volgende kwartaal. Ook de huisartskosten en overige medische kosten blijken min of meer stabiel te zijn: mensen die in het ene kwartaal meer huisartskosten of overige medische kosten maken, doen dat gemiddeld ook meer in het volgende kwartaal. Verder zien we ook voor alle drie de variabelen in beide groepen een vertraagd effect: hogere huisartskosten in het eerste kwartaal voorspellen hogere huisartskosten in het derde kwartaal, niet alleen indirect via hogere huisartskosten in

Tabel 2 Coëfficiënten en significantie voor alle getoetste relaties van de modellen uit figuren 1 en 2.

\begin{tabular}{|c|c|c|c|c|c|c|}
\hline & \multicolumn{3}{|c|}{ Werknemers zonder chronische aandoening } & \multicolumn{3}{|c|}{ Werknemers met chronische aandoening } \\
\hline & $\begin{array}{c}\text { Ongestan- } \\
\text { daardiseerde } \\
\text { parameter }\end{array}$ & $\begin{array}{l}\text { Gemiddelde } \\
\text { gestandaar- } \\
\text { diseerde } \\
\text { parameter }\end{array}$ & $\mathrm{p}<$ & $\begin{array}{l}\text { Ongestan- } \\
\text { daardiseerde } \\
\text { parameter }\end{array}$ & $\begin{array}{l}\text { Gemiddelde } \\
\text { gestandaar- } \\
\text { diseerde } \\
\text { parameter }\end{array}$ & $\mathrm{p}<$ \\
\hline \multicolumn{7}{|l|}{ Cross-sectionele covarianties (PSY) } \\
\hline verzuim - huisartskosten & 0,03 & 0,10 & 0,001 & 0,07 & 0,20 & 0,001 \\
\hline \multirow[t]{2}{*}{ verzuim - overige medische kosten } & 0,05 & 0,11 & 0,001 & 0,10 & 0,22 & 0,001 \\
\hline & 0,24 & 0,35 & 0,001 & 0,29 & & \\
\hline \multicolumn{7}{|l|}{ Longitudinale regressiegewichten (BETA) } \\
\hline verzuim $1=>$ verzuim 2 & 0,23 & 0,23 & 0,001 & 0,52 & 0,53 & 0,001 \\
\hline verzuim1 $=>$ huisartskosten 2 & 0,02 & 0,01 & ns & 0,03 & 0,02 & ns \\
\hline verzuim $1=>$ overige medische kosten 2 & 0,01 & 0,01 & ns & 0,04 & 0,02 & ns \\
\hline verzuim $1=>$ verzuim 3 & 0,12 & 0,13 & 0,001 & 0,16 & 0,17 & 0,001 \\
\hline huisartskosten $1=>$ verzuim 2 & 0,01 & 0,02 & ns & 0,04 & 0,06 & 0,01 \\
\hline huisartskosten 1 => huisartskosten 2 & 0,22 & 0,21 & 0,001 & 0,30 & 0,29 & 0,001 \\
\hline huisartskosten $1=>$ overige medische kosten 2 & 0,12 & 0,08 & 0,001 & 0,11 & 0,08 & 0,001 \\
\hline huisartskosten $1=>$ huisartskosten 3 & 0,16 & 0,16 & 0,001 & 0,17 & 0,16 & 0,001 \\
\hline overige medische kosten $1=>$ verzuim 2 & 0,01 & 0,02 & ns & 0,01 & 0,02 & ns \\
\hline overige medische kosten $1=>$ huisartskosten 2 & 0,03 & 0,04 & 0,05 & 0,03 & 0,04 & 0,05 \\
\hline overige medische kosten $1=>$ overige medische kosten 2 & 0,27 & 0,26 & 0,001 & 0,41 & 0,40 & 0,001 \\
\hline overige medische kosten $1=>$ overige medische kosten 3 & 0,22 & 0,21 & 0,001 & 0,17 & 0,16 & 0,001 \\
\hline
\end{tabular}

Noot: De overeenkomstige ongestandaardiseerde parameters zijn steeds aan elkaar gelijkgesteld (zie methode). Bijvoorbeeld: verzuim1 $=>$ verzuim 2 is identiek aan verzuim $2=>$ verzuim3 en aan verzuim $3=>$ verzuim4. Alleen dit eerste pad is in de tabel weergegeven.

Het model voor werknemers met chronische aandoening verschilt van het model voor werknemers zonder chronische aandoening: $\Delta \chi^{2}$ ( $\left.d f=12\right)=$ 277,94, $p<.001$. De fitmaten van het uiteindelijke model zijn: $\chi^{2}(\mathrm{df}=171)=485,37, p<.001 ; \mathrm{CFI}=0,96 ; \mathrm{NNFI}=0,95 ; \mathrm{SRMR}=0,07$. 
het tweede kwartaal, maar ook rechtstreeks. Ditzelfde zien we bij verzuim en bij overige medische kosten. Dit patroon versterkt de stabiliteit van deze variabelen.

De meest interessante paden zijn uiteraard die van huisartskosten en overige medische kosten in het ene kwartaal naar verzuim in het volgende kwartaal en omgekeerd. Uit tabel 2 blijkt dat geen van deze paden significant is voor werknemers zonder aandoening (figuur 1). Er is dus geen evidentie bij deze groep dat verzuim voorspellend is voor medische consumptie of omgekeerd. Bij werknemers met een chronische aandoening vinden we wel een longitudinale relatie tussen medische consumptie en verzuim: huisartskosten in het ene kwartaal voorspellen verzuim in het volgende kwartaal (figuur 2). Uit figuur 2 blijkt dat werknemers met een chronische aandoening relatief vaak naar de huisarts gaan in de periode voordat zij uitvallen uit het werk. Verzuim voorspelt niet de huisartskosten en ook is er geen longitudinale relatie tussen verzuim en overige medische kosten. Verder zien we dat huisartskosten en overige medische kosten in beide groepen elkaar voorspellen: naarmate de huisartskosten in het ene kwartaal hoger zijn, zijn de overige medische kosten in het volgende kwartaal hoger. Het omgekeerde effect treedt ook op, maar is minder sterk.

\section{DISCUSSIE}

Uit dit onderzoek blijkt dat medische consumptie een deel van het verzuim voorspelt, maar alleen voor werknemers met een chronische aandoening. Bij werknemers met een chronische aandoening voorspellen huisartskosten het verzuim. Blijkbaar gaan werknemers met een chronische aandoening relatief vaak naar de huisarts in de periode voordat zij uitvallen uit het werk. Deze resultaten zijn in overeenstemming met twee eerdere studies. ${ }^{15,16}$ Bij werknemers met een chronische aandoening vonden we geen evidentie dat de overige medische kosten voorspellend zijn voor verzuim of omgekeerd. Bij deze groep zullen de overige medische kosten (dus exclusief huisartskosten) wellicht vooral bepaald worden door de aard van de chronische aandoening en in mindere mate verband houden met tijdelijke schommelingen in de gezondheid die verzuim kunnen veroorzaken. Bij werknemers zonder chronische aandoening blijkt medische consumptie niet voorspellend te zijn voor het ziekteverzuim in de daaropvolgende periode. Bij deze groep zijn schommelingen in de gezondheid die artsbezoek noodzakelijk maken wellicht niet groot genoeg om een hoger verzuim te voorspellen.

Verder blijkt uit het onderzoek dat bij zowel werknemers met als zonder chronische aandoening huisartskosten voorspellend zijn voor overige medische kosten in het kwartaal daarna en dat in mindere mate overige me-
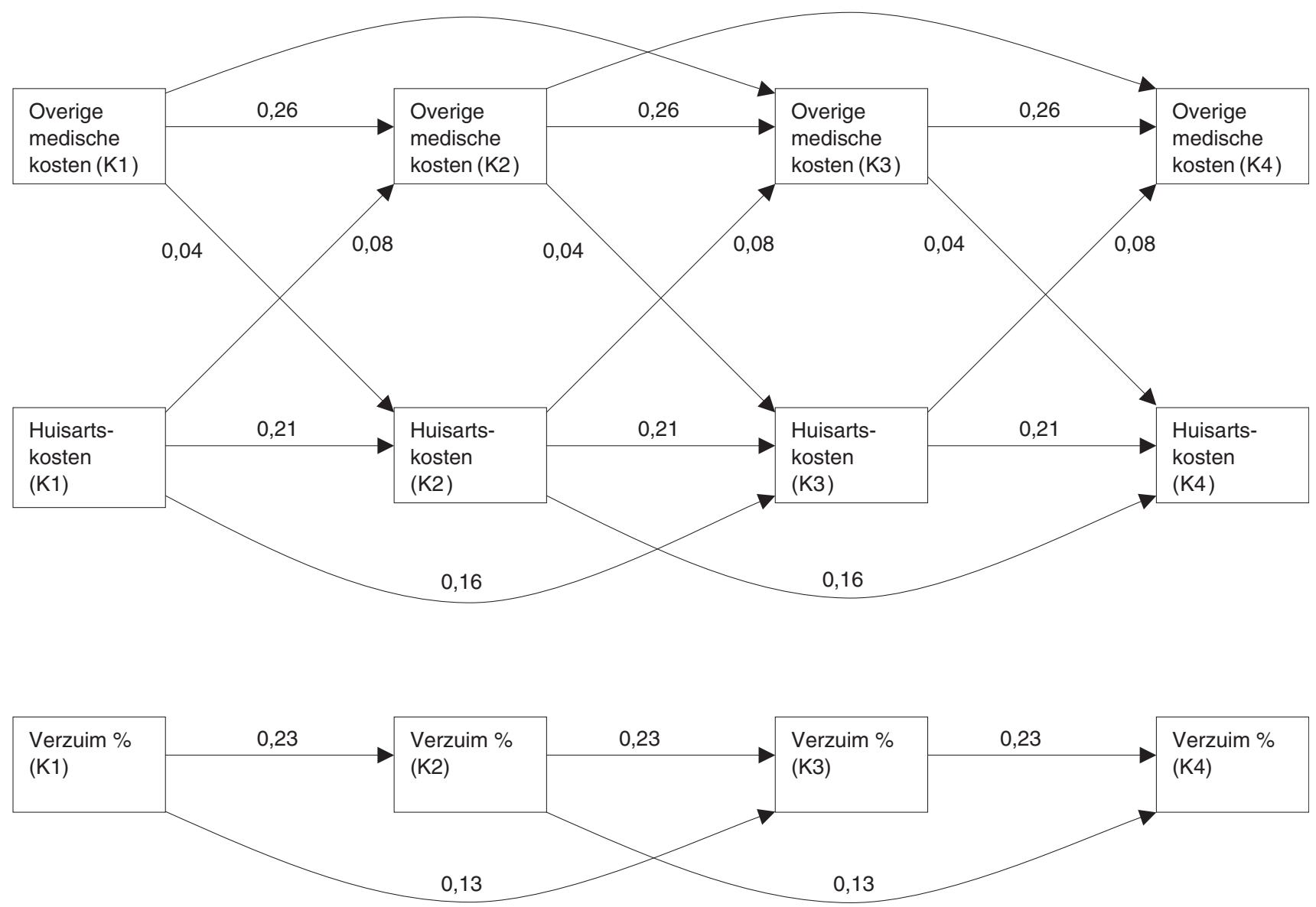

Figuur 1 Het definitieve model met (gemiddelde) gestandaardiseerde coëfficiënten voor de significante longitudinale relaties tussen huisartskosten, overige medische kosten en verzuim bij werknemers zonder chronische aandoening

De gegevens beslaan vier kwartalen: $\mathrm{K}_{1}=$ vierde $\mathrm{kwartaal}$ 2002; $\mathrm{K}_{2}=$ eerste $\mathrm{kwartaal}$ 2003; $\mathrm{K}_{3}=$ tweede $\mathrm{kwartaal} 2003 ; \mathrm{K}_{4}=$ derde $\mathrm{kwartaal} 2003$. 


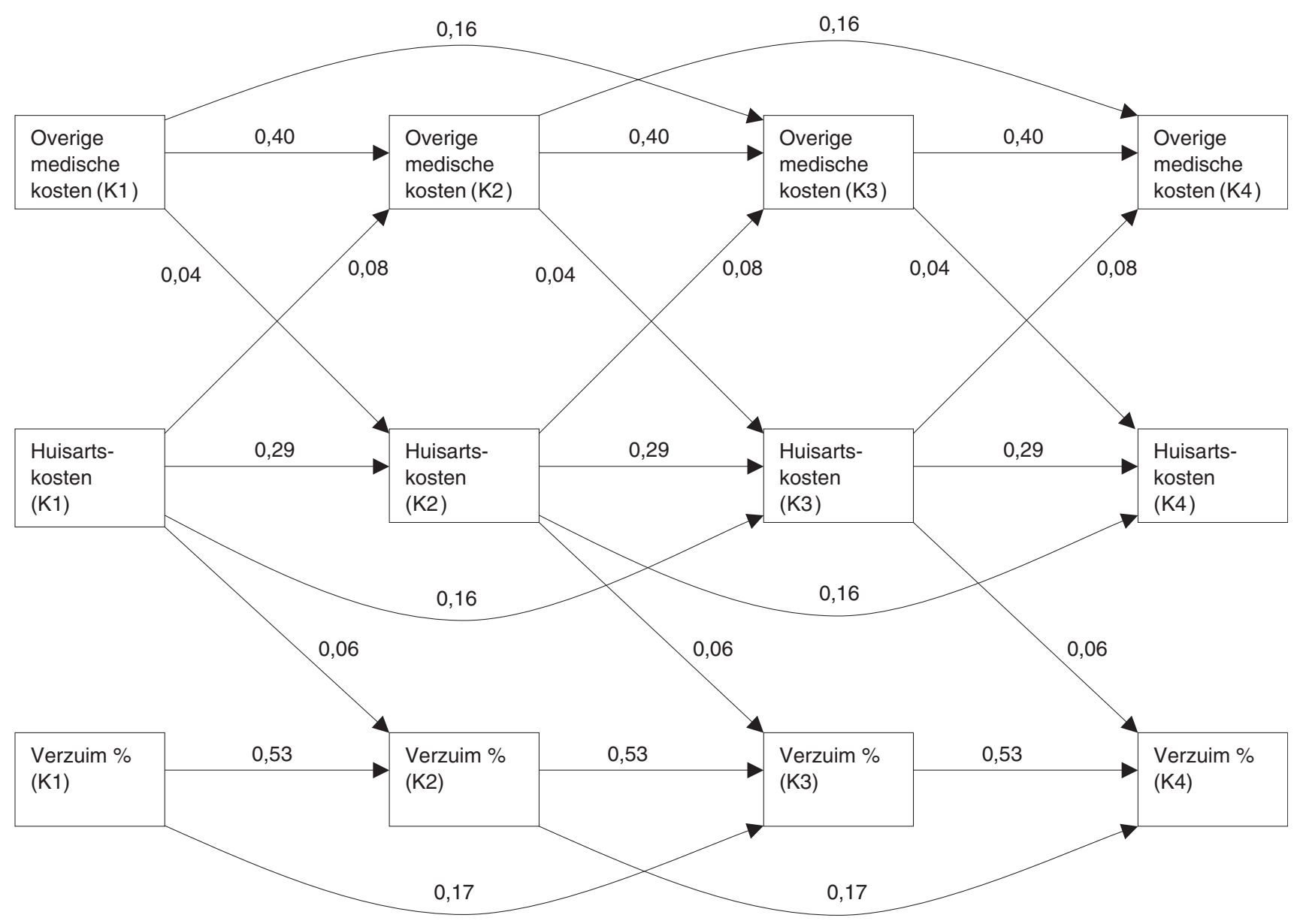

Figuur 2 Het definitieve model met de (gemiddelde) gestandaardiseerde coëfficiënten voor significante longitudinale relaties tussen huisartskosten, overige medische kosten en verzuim bij werknemers met een chronische aandoening.

De gegevens beslaan vier kwartalen: $\mathrm{K}_{1}=$ vierde kwartaal 2002; K2 = eerste kwartaal 2003; K3 = tweede kwartaal 2003 ; K4 = derde kwartaal 2003.

dische kosten de huisartskosten in het volgende kwartaal voorspellen. Dit is niet verwonderlijk: bij een verslechterende gezondheidstoestand gaan mensen doorgaans eerst naar de huisarts, die hen dan zonodig verwijst naar andere zorgverleners. Ook zal de nazorg na bijvoorbeeld een ziekenhuisopname weer (gedeeltelijk) door de huisarts worden gegeven, wat het omgekeerde effect van overige medische kosten op huisartskosten kan verklaren.

We hebben ook gekeken naar de stabiliteit van verzuim en medische consumptie over de vier kwartalen. Het verzuimpercentage blijkt stabiel in de tijd, vooral voor werknemers met een chronische aandoening. Deels kan dit het gevolg zijn van mensen die langdurig verzuimen, waarbij de verzuimperiode de kwartaalgrenzen overschrijdt. De huisartskosten blijken redelijk stabiel. Sommige werknemers zijn geneigd om regelmatig naar de huisarts te gaan en anderen niet en deze individuele verschillen blijven min of meer constant gedurende dit onderzoek. Ook de overige medische kosten zijn redelijk stabiel, waarbij de stabiliteit hoger is voor werknemers met een chronische aandoening. Sommigen van hen maken veel medische kosten en doen dat consistent over de tijd, terwijl anderen consistent minder kosten maken. Dit is waarschijnlijk afhankelijk van de aard van de aandoening: sommige aandoeningen zijn duur vanwege me- dicijnen of terugkerende zorg terwijl andere aandoeningen relatief weinig vaste kosten met zich meebrengen. Uit verschillende onderzoeken is gebleken dat specifieke aandoeningen een hogere medische consumptie met zich meebrengen. ${ }^{2,5-9}$

De kracht van dit onderzoek ligt in de grote steekproef en de mogelijkheid tot longitudinaal onderzoek aan geregistreerde gegevens. Dit onderzoek vond wel plaats bij een selecte groep: werknemers die allen in één groot ziekenhuis werkten, veelal hoog opgeleid en vrouw. De effecten zijn echter gevonden na correctie voor deze factoren. Daarom verwachten we dat de resultaten ook algemener geldig zijn. Ook is ondertussen het zorgstelsel en daarmee de vergoedingen in het basispakket veranderd. Wij verwachten hierdoor geen grote veranderingen in de modellen, maar verder onderzoek moet dit uitwijzen.

Een beperking van het onderzoek is dat de longitudinale effecten klein lijken. Longitudinale effecten zijn echter altijd klein en lastig aan te tonen. Dit heeft vooral methodologische oorzaken en betekent niet dat de feitelijke invloed van huisartsbezoek op verzuim gering is bij werknemers met een chronische aandoening. Het longitudinale effect van huisartsbezoek op verzuim is namelijk gecorrigeerd voor de cross-sectionele samenhang tussen beide variabelen en voor het verzuim in het voor- 
gaande kwartaal. Hierdoor zal er weinig systematische variantie overblijven die verklaard kan worden door huisartsbezoek.

Uit dit onderzoek komt het beeld naar voren dat werknemers met een chronische aandoening bij toename van gezondheidsklachten eerst naar de huisarts gaan, waarna verzuim volgt. Bij werknemers met een chronische aandoening is huisartsbezoek dus voorspellend voor verzuim. Een mogelijke verklaring voor deze bevinding is dat werknemers met een chronische aandoening bij toenemende gezondheidsklachten in eerste instantie vaak doorwerken hoewel zij ziek zijn. Dergelijk sickness presenteeism blijkt vaker voor te komen bij werkenden met gezondheidsklachten dan bij gezonde werkenden. ${ }^{23} \mathrm{Mo-}$ gelijk leidt dit in een later stadium alsnog tot verzuim indien de gezondheid onvoldoende herstelt.

Omdat de medische consumptie vooraf gaat aan het verzuim kan deze informatie gebruikt worden om het verzuim te beïnvloeden. Huisartsen kunnen bijvoorbeeld extra alert zijn wanneer werknemers met een chronische aandoening frequenter op het spreekuur komen. De huisarts zou dan kunnen vragen of de klachten een belemmering voor het uitvoeren van het werk vormen. De huisarts kan dan samen met de werknemer kijken of verzuim tot een minimum beperkt of voorkomen kan worden. De huisarts kan zonodig ook contact opnemen met de bedrijfsarts van de werknemer. Van den Heuvel et al. ${ }^{19}$ vonden dat werknemers die verzuimen een hogere bijdrage wensen van zowel de huisarts als de bedrijfsarts bij herstel en terugkeer naar werk. Uit dit onderzoek blijkt ook dat 94\% van de werknemers geen bezwaar heeft tegen contact tussen de huis- en bedrijfsarts, mits hen daarvoor om toestemming wordt gevraagd. Hoewel het niet duidelijk is of werknemers die (nog) niet verzuimen ook van mening zijn dat de huisarts meer aandacht moet besteden aan het werk, lijkt dit wel wenselijk te zijn om daarmee toekomstig verzuim te voorkomen of te beperken.

Dit onderzoek roept ook interessante vragen op. Hangt de voorspellende waarde van huisartsbezoek op verzuim af van het soort chronische aandoening? Zijn bepaalde vormen van medische consumptie voor bepaalde groepen werknemers met gezondheidsproblemen effectiever dan andere? Wanneer we ook deze factoren in kaart brengen kunnen we misschien in de toekomst specifieke groepen werknemers herkennen, zorg op maat geven en het verzuim terugbrengen.

\section{DANKWOORD}

Het onderzoek is gefinancierd door het College voor Zorgverzekeringen (CVZ). Deze publicatie is tot stand gekomen in het kader van het programma 'Arbeid en Gezondheid' dat TNO uitvoert in samenwerking met het Ministerie van VWS.

\section{ABSTRACT}

The relation between medical costs and sickness absence among employees of a large hospital

Higher medical costs are linked to higher sickness absence but it is unclear how medical costs and sickness absence influence each other over time. Therefore, in this study we focus on the longitudinal relation between medical costs and sickness absence. This study was carried out among 2317 employees of a large hospital in the Netherlands (response rate was $44 \%$ ). The data include registered sickness absence and registered medical costs over one year, divided into four successive three-month periods. Longitudinal analysis was carried out with LISREL.

This study shows that medical costs in one quarter partly predict sickness absence in the next quarter. Results differ for employees with and without a chronic illness. Medical costs related to visiting the GP (but not other medical costs) predict sickness absence for employees with a chronic illness, but not for employees without a chronic illness. Other medical costs (but not GP-related medical costs) do not predict sickness absence for employees with or without a chronic illness. It is concluded that the GP could play a role in detecting employees at risk for sickness absence by being alert when seeing employees with a chronic illness. Together the GP and employee should explore possibilities to minimize or prevent sickness absence.

Key words: Medical costs, sickness absence, general practitioner, employees, chronic illness

\section{LITERATUUR}

1. Corney $R H$. Sex differences in general practice attendance and help seeking for minor illness. J Psychosom Res 1990;34:52534.

2. Krasnik A, Hansen E, Keiding N, Sawitz A. Determinants of general practice utilization in Denmark. Dan Med Bull 1997; 44(5):556-60.

3. Miilunpalo S, Vuori I, Oja P, Pasanen M, Urponen H. Self-rated Health status as a health measure: the predictive value of selfreported health status on the use of physician services and on mortality in the working-age population. J Clin Epidemiol 1997;50:517-28.

4. Al-Windi A, Dag E, Kurt S. The influence of perceived wellbeing and reported symptoms on health care utilization: a population based study. J Clin Epidemiol 2002;55:60-6.

5. Kolk AMM, Hanewald GJFP, Schagen S, Gijsbers van Wijk CMT. Predicting medically unexplained physical symptoms and health care utilization: a symptom-perception approach. J Psychosom Res 2002;52:35-44.

6. Laitinen-Krispijn S, Bijl R. Werk, psyche en ziekteverzuim. Aard en omvang van psychische stoornissen, ziekteverzuim en zorggebruik in de beroepsbevolking. Utrecht: Trimbos-instituut, 2002.

7. Andrea $H$. Fatigue and mental health problems in the working population: descriptives and associations with consulting a physician. (Proefschrift) Maastricht: Universiteit Maastricht, 2003.

8. Andrea H, Beurskens AJHM, Metsemakers JFM et al. Health and psychosocial work characteristics of employees who did or did not consult the general practitioner in relation to work. Int Arch Occup Environ Health 2003;76:69-74.

9. Andrea H, Beurskens AJHM, Metsemakers JFM et al. Health problems and psychosocial work environment as predictors of long term sickness absence in employees who visited the occupational physician and/or general practitioner in relation 
to work: a prospective study. Occup Environ Med 2003b;60: 295-300.

10. Carr-Hill RA, Rice N, Roland M. Socioeconomic determinants of rates of consultation in general practice based on fourth national morbidity survey of general practices. BMJ 1996;312: 1008-13.

11. Lin MR, Tsauo JY, Wang J. Determinants of economic costs related to low back pain among nurses at a university hospital. Int J Occup Environ Health 1996;2:257-63.

12. Joish VN, Donaldson G, Stockdale W et al. The economic impact of GERD and PUD: examination of direct and indirect costs using a large integrated employer claims database. Curr Med Res Opinions 2005;21:535-543.

13. White AG, Birnbaum HG, Mareva MN et al. Economic burden of illness for employees with painful conditions. JOEM 2005; 47:884-92.

14. Molano SM, Burdorf A, Elders LAM. Factors associated with medical care-seeking due to low-back pain in scaffolders. Am J Ind Med 2001;40:275-81.

15. Houtman ILD, Schoemaker CG, Blatter BM et al. Psychische klachten, interventies en werkhervatting. De prognosestudie INVENT. Heerhugowaard: PlantijnCasparie, 2002.

16. Nieuwenhuijsen K, Verbeek JHAM, Boer AGEM de et al. Supervisory behaviour as a predictor of return to work in employees absent from work due to mental health problems. Occup Environ Med 2004;61:817-23.

17. Banks I. No man's land: Men, illness, and the NHS. BMJ 2001; 323:1058-60.
18. Carlisle R, Johnstone S. The relationship between census-derived socio-economic variables and general practice consultation rates in three town centre practices. Br J Gen Pract 1998;48: 1675-8.

19. Heuvel FMM van den, Steenbeek R, Buijs PC. Werknemers wensen bij verzuim een prominentere rol van bedrijfsarts én huisarts.TBV 2006; 14(7):299-305.

20. Smulders $P G W$. Ziekteverzuim: hoogte, oorzaken, aandoeningen, werkgebondenheid en maatregelen. Secundaire analyses Nationale Enquête Arbeidsomstandigheiden 2003. Hoofddorp: TNO, 2004.

21. Hu L, Bentler PM. Fit indices in covariance structure modeling: Sensitivity to underparameterized model misspecification. Psychol Meth 1998;3:424-53.

22. Hoijtink HJA, Jonge J de. Beginselen van covariantiestructuuranalyse. Gedrag en Organisatie 2007;20:57-81.

23. Aronson G, Gustafsson K, Dallner M. Sick but yet at work. An empirical study of sickness presenteeism. J Epidemiol Comm Health 2000;54:502-9.

\section{CORRESPONDENTIEADRES}

Dr. R. Steenbeek, TNO Kwaliteit van Leven / Arbeid, Postbus 718, 2130 AS Hoofddorp, tel. 023-5549432, e-mail: romy.steenbeek@tno.nl

Voor publicatie aanvaard in juni 2007. 